\title{
EXPLORING TERTIARY ENGLISH-MAJORED STUDENTS' ACADEMIC WRITING DIFFICULTIES
}

\author{
Tran Quoc Thao ${ }^{*}$, Nguyen Hoang Nhat Quyen ${ }^{2}$ \\ ${ }^{1}$ Ho Chi Minh City University of Technology (HUTECH) \\ ${ }^{2}$ The University of Dalat
}

\section{ABSTRACT}

This paper endeavors to present the findings of a study on the writing difficulties in terms of six aspects in academic writing, namely organization/sequence, vocabulary/spelling, grammar, supporting ideas, punctuation/capitalization, and unity and coherence encountered by Englishmajored students. The research participants were 126 English-majored students from a higher education institution in Lam Dong province, Vietnam. The participants took part in answering closed-ended questionnaires. Quantitative data were analyzed by SPSS in terms of descriptive statistics. The findings revealed that participants often faced a variety of writing difficulties in academic writing. Remarkably, among six aspects of academic writing difficulties, participants had more difficulties in deploying organization/sequence and using grammar and punctuation/capitalization than the other aspects. Additionally, the aspect of unity and coherence in academic writing was the least difficult one from which they suffered in academic writing. Pedagogical implications are recommended for improving the quality of the teaching and learning of academic writing in the research context and other similar ones.

Keywords: academic writing; English-majored student; higher education institution; writing difficulties

Received: 08/10/2020; Revised: 16/10/2020 ; Published: 20/10/2020

\section{TÌM HIỂU KHÓ KHĂN CỦA SINH VIÊN CHUYÊN NGÀNH NGÔN NGŨ๋ ANH TRONG KHI VIẾT HỌC THUẬT}

\author{
Trần Quốc Thao ${ }^{*}$, Nguyễn Hoàng Nhật Quyên ${ }^{2}$ \\ ${ }^{I}$ Trường Đại học Công nghệ Thành phố Hồ Chỉ Minh \\ ${ }^{2}$ Truò̀ng Đại học Đà Lạt
}

\section{TÓM TẮT}

Bài báo này trình bày kết quả nghiên cứu sáu nhóm khó khăn trong viết học thuật, cụ thể là cấu trúc/ trình tư, tù vựng/chinh tả, ngũ pháp, ý bổ trợ, dấu câu/ viết hoa, liển kết và mạch lac mà sinh viên chuyên ngành Ngôn ngữ Anh gặp phải. Nghiên cứu này gồm có 126 sinh viên chuyên ngành Ngôn ngữ Anh tại một trường đại học ở tỉnh Lâm Đồng tham gia trả lời bảng câu hỏi. Dữ liệu định lượng được thống kê mô tả bằng phần mềm SPPS. Kết quả cho thấy, đối tượng tham gia nghiên cứu gặp nhiều khó khăn trong viết học thuật. Trong sáu nhóm khó khăn, đối tượng tham gia nghiên cứu gặp khó khăn về cấu trúc/ trình tư và sử dụng ngũ pháp và dấu câu/viết hoa nhiều hơn các nhóm khó khăn khác. Ngoài ra, họ gặp ít khó khăn nhất về liên kết và mạch lạc trong quá trình viết học thuật. Dựa trên những kết quả này, các đề xuất nhằm cải thiện chất lượng dạy và học viết học thuật được đưa ra cho ngữ cảnh nghiên cứu này và các ngữ cảnh tương tự.

Từ khóa: viết học thuật; sinh viên chuyên ngành Ngôn ngũ Anh; bậc đại học; khó khăn trong khi viết

Ngày nhận bài: 08/10/2020; Ngày hoàn thiện: 16/10/2020; Ngày đăng: 20/10/2020

\footnotetext{
* Corresponding author. Email: tq.thao@hutech.edu.vn
}

DOI: https://doi.org/10.34238/tnu-jst.3686 


\section{Introduction}

Writing is a difficult skill in ESL/EFL teaching and learning. According to Grami [1], writing is a difficult skill to learn or teach because it is not a simple cognitive activity but rather complex psychological production that requires "careful thought, discipline and concentration" (p. 9). In addition, as academic writing is a challenging skill, especially, in a second and foreign language, difficulties in academic writing should be greatly considered. Fadda [2] states that academic writing is connected with thinking or conscious mental processes because of an outcome of the part of a student that makes it possible for him or her to think, feel emotions, and understand things. What is more, EFL learners in some areas may encounter a number of difficulties in academic writing. Casanave and Hubbard [3] and Rabab'ah [4] have highlighted that Asian students are assumed to confront obstacles in academic writing and find it hard to get acquainted with English academic writing. The common difficulties in academic writing can be grouped as organization/sequence, vocabulary/spelling, grammar, supporting ideas, punctuation/capitalization, and unity and coherence [1-4].

In the context of Vietnam, EFL learners are observed to encounter different difficulties in writing and expressing their ideas through writing. Despite the fact that the majority of them have learned English since elementary school, they still face many writing problems. As for English majored students, many of them are seen to struggle with academic writing during their studies. They have difficulties in the writing process in terms of text organization and sentence structures, and they do not have sufficient vocabulary, especially academic words, and language structures to express their ideas while writing. What is more, their writing is often influenced by their mother tongue, so they write English by translating word by word from Vietnamese to English, which causes confusion for readers.

Prior studies in different contexts have revealed that students confront a number of difficulties in academic writing. Internationally, many researchers [2], [5-9] have been involved in examining writing difficulties encountered by EFL learners. Boonpattanaporn [8] did a study on English essay writing strategies used and difficulties faced by English majored students. The study involved 272 students in answering a questionnaire. The findings indicated that participants used direct translation strategy most and encountered difficulties in getting the readers' attention, getting started, spending too long reading and thinking, using verb tenses and word choice, and ordering ideas. Fadda [2] conducted a study on determining the academic writing difficulties faced by university students. The sample was 50 postgraduate students answering the questionnaire. The findings revealed that participants faced many difficulties in academic writing such as distinguishing between spoken and written English, making an outline before writing a draft, identifying the skills needed for successful writing, and avoiding plague words and phrases. In 2015, Awad [7] did a study on examining the punctuation mistakes made by university English majors. The participants were 100 students. The results showed that participants committed different errors such as the overuse of comma, the incorrect use of the capital letter, the wrong use of the quotation marks and the misuse of the semicolon. In the context of Vietnam, Luong and Nguyen [10] conducted a study on problems and process of writing of a Vietnamese student. The data were collected from in-depth interviews. The finding showed that the participants did not care about grammar or spelling mistakes, and he applied a lot of behaviors in his 
compositions. Another study conducted by Chi and Nguyen [11] explored the tertiary EFL students' paraphrasing ability and challenges students faced when paraphrasing. They collected data from students' texts and interviews. The results indicated that participants often used synonyms for paraphrasing, and they had many languagerelated difficulties when paraphrasing such as lack of understanding of the source text and vocabulary. Within the scope of this study, this study attempts to explore the academic writing difficulties encountered by English majored students at a tertiary institution in Lam Dong Province. The following research question is addressed: What are academic writing difficulties encountered by English majored students at a higher education institution in Lam Dong province?

\section{Research methodology}

\subsection{Research site and participants}

The quantitative study was conducted at a higher education institution in Lam Dong province, Vietnam. The Faculty of Foreign Languages at the research site offers two English language-training programs, namely English Language Education and English Language Studies. English majored students learn English language skills of Listening, Speaking, Reading and Writing in the first two years of their BA program. For writing skills, students have to learn academic writing in the first year.

The number of research participants was 126 second-year English majored students who were conveniently sampled. Just over a half (50.8\%) of participants' previous writing score was from less than or equal to 5.0 to 6.9 , and the rest of them (49.2\%) got less than 5.0 out of 10 . The vast majority of participants $(81 \%)$ spent from 1 to 2 hours a day practicing English writing, while the minority of them (11.9\%) practiced English writing more than 2 hours. Additionally, a very small number of participants reported that they spent less than 1 hour a day. Finally, all participants (100\%) did not have any experience of taking any international language tests.

\subsection{Research instrument}

The closed-ended questionnaire was employed for data collection. The closedended questionnaire which was adopted from Tanaka [12] included two parts: Part A was about the personal information of participants; Part B contained main items investigating (I) Students' difficulties in academic writing (17 items) in terms of six categories: Organization/ Sequence in writing, Vocabulary/ Spelling, Grammar, Supporting Ideas, Punctuation/ Capitalization and Unity and Coherence. The five-point Likert scale (1: Never; 2: Seldom; 3: Sometimes; 4: Often; 5: Always) was used. The questionnaire was translated into Vietnamese so that participants did not encounter any difficulty in answering the questionnaire. The Cronbach's alpha of the questionnaire was .90, which means the questionnaire was very reliable.

\subsection{Procedures for data collection and analysis}

With respect to data collection, the questionnaire had been piloted for their validity before it was used officially. Then, 150 questionnaires were administered to participants in person. Explanations were given when necessary. It took participants 2025 minutes to finish the questionnaire. The returned questionnaires were 126 officially accepted. Regarding data analysis, the quantitative data collected from questionnaires were analyzed by the SPSS in terms of descriptive statistics. The five-point Likert-scale from Never to Always was interpreted in terms of mean (M) score as $\mathrm{M}=$ 1.00 - 1.80: Never; $\mathrm{M}=1.81$ - 2.60: Rarely; $\mathrm{M}=2.61$ - 3.40: Sometimes; $\mathrm{M}=3.41$ - 4.20: Often; $\mathrm{M}=4.21-5.00$ : Always. 


\section{Results and discussion}

\subsection{Results}

\subsubsection{English-majored students' academic writing difficulties}

It can be seen from Table 1 that the overall mean score of English-majored students' difficulties in academic writing is 4.11 (out of 5). However, the standard deviation (SD) of .96 indicates that the distribution of students who had difficulties regarding academic writing was rather scattered, but not seriously. This finding means that students often encountered certain difficulties in their academic writing tasks.

A majority of students showed their high agreement of the difficulties in academic writing. Particularly, the difficulties in organization/ sequence in writing and in punctuation/ capitalization had the highest mean score $(\mathrm{M}=4.40)$, while the lowest mean score $(\mathrm{M}=3.55 ; \mathrm{S} . \mathrm{D}=.83)$ belonged to difficulties in unity and coherence. This means that students found organization/ sequence in writing and punctuation/ capitalization more difficult than the other groups. In addition, grammar was a hard element faced by students $(\mathrm{M}=4.29 ; \mathrm{S} . \mathrm{D}=.98)$, and vocabulary/ spelling was seen as one of their challenges $(\mathrm{M}=4.12 ; \mathrm{S} . \mathrm{D}=.77)$. Moreover, students agreed that supporting ideas was one of elements of difficulties in academic writing $(\mathrm{M}=3.93$; S.D = .69). This result showed that participants viewed academic writing as difficult factor in English learning.

\subsubsection{English-majored students' difficulties}

- Academic writing difficulties in organization/ sequence in writing

Table 2 illustrates the students' levels of agreement about the difficulties in academic writing in terms of organization/ sequence. Specifically, the students strongly agreed with they did not know the right pattern for a specific type of writing (item $1: \mathrm{M}=4.42$, $\mathrm{SD}$ $=.97$ ) and how to organize ideas for the assigned writing (item $3: \mathrm{M}=4.42, \mathrm{SD}=$ .93). The two items had the highest mean score in this term $(M=4.42)$. Moreover, the item that they could not make an outline including the main points of their assignment before writing also made them feel less confident in writing (item $4: \mathrm{M}=4.40, \mathrm{SD}=$ .93). In addition, they showed their strong agreement that they did not know how to start writing (item $2: \mathrm{M}=4.36, \mathrm{SD}=.87$ ).

Table 1. English-majored students' academic writing difficulties

\begin{tabular}{lccc}
\hline \multicolumn{1}{c}{1 17 items } & \multicolumn{2}{c}{$\mathbf{N = 1 2 6}$} \\
\cline { 2 - 3 } & $\mathbf{M}$ & SD \\
\hline Difficulties in organization/ sequence in writing & 4.40 & .87 \\
Difficulties in vocabulary/ spelling & 4.12 & .77 \\
Difficulties in grammar & 4.29 & .98 \\
Difficulties in supporting ideas & 3.93 & .69 \\
Difficulties in punctuation/ capitalization & 4.40 & .93 \\
Difficulties in unity and coherence & 3.55 & .83 \\
\multicolumn{1}{c}{ Total } & 4.11 & .96 \\
\hline
\end{tabular}

Table 2. English-majored students' academic writing difficulties in terms of organization/ sequence

\begin{tabular}{clcc}
\hline \multirow{2}{*}{ No. } & \multicolumn{1}{c}{$\mathbf{4}$ items } & \multicolumn{2}{c}{$\mathbf{N = 1 2 6}$} \\
\cline { 3 - 4 } & & $\mathbf{M}$ & SD \\
\hline 1 & I don't know the right pattern for a specific type of writing. & 4.42 & .97 \\
2 & I don't know how to start writing. & 4.36 & .87 \\
3 & I don't know how to organize ideas for the assigned writing. & 4.42 & .93 \\
4 & I cannot make an outline including the main points of my assignment & 4.40 & .93 \\
\hline
\end{tabular}


- Academic writing difficulties in vocabulary/ spelling

Table 3 shows that vocabulary/spelling was really one of the important difficulties affecting academic writing. The majority of the participants claimed that they could not differentiate between spoken words and written ones (item 6: $\mathrm{M}=4.39, \mathrm{SD}=.59$ and found it hard to use correct words (item 7: M $=4.39, \mathrm{SD}=.89$ ), which was the highest mean score of this type. Besides, the participants showed their agreement that they did not have enough vocabulary to write (item 5: $\mathrm{M}=4.36, \mathrm{SD}=.79)$. Finally, the lowest mean score of this term belonged to the use of the correct spelling of words (item 8: $\mathrm{M}=$ 3.33, $\mathrm{SD}=.90)$.

- Academic writing difficulties in grammar

According to the data from Table 4, the participants realized that grammar had a significantly influence on academic writing. Most of the students could not differentiate between formal structures and informal ones (item 11: $\mathrm{M}=4.42, \mathrm{SD}=.90$ ), which was the most difficult item in grammar. Next, the difficulty in using correct tenses in writing was always a serious problem (item 9: $\mathrm{M}=4.40$, $\mathrm{SD}=.90)$. The lowest mean score of grammar was difficulties in using correct structures in writing (item 10: $\mathrm{M}=4.03, \mathrm{SD}=.52$ ).

- $\quad$ Academic writing difficulties in writing supporting ideas

Table 5 describes that supporting ideas had effects on academic writing. Students had many difficulties while finding ideas relevant to the topic (item $12: \mathrm{M}=4.40, \mathrm{SD}=.70$ ) and finding supporting ideas (item 13: $\mathrm{M}=3.45$, $\mathrm{SD}=.88)$.

- Academic writing difficulties in punctuation and capitalization

Table 6 illustrates difficulties in academic writing in terms of Punctuation/ Capitalization. Punctuation is not only an integral part of the forms of an academic, but also a more powerful style effect when used well, so it is clear that the majority of participants agreed that they found difficulties in using punctuations (item 14: $\mathrm{M}=4.40, \mathrm{SD}$ $=.62)$. This mean score was the same as item $15(\mathrm{M}=4.40, \mathrm{SD}=.82)$ "I have difficulties in using capitalization").

Table 3. English-majored students' academic writing difficulties in terms of vocabulary/spelling

\begin{tabular}{clcc}
\hline \multirow{2}{*}{ No. } & \multicolumn{1}{c}{ 4 items } & \multicolumn{2}{c}{ N=126 } \\
\cline { 3 - 4 } & & M & SD \\
\hline 5 & I don't have enough vocabulary to write. & 4.36 & .79 \\
6 & I can't differentiate between spoken words and written ones. & 4.39 & .59 \\
7 & I find it hard to use correct words. & 4.39 & .89 \\
8 & I have difficulties in using the correct spelling of words. & 3.33 & .90 \\
\hline
\end{tabular}

Table 4. English-majored students' academic writing difficulties in terms of grammar

\begin{tabular}{clcc}
\hline \multirow{2}{*}{ No. } & \multicolumn{2}{c}{ 3 items } & \multicolumn{2}{c}{ N=126 } \\
\cline { 3 - 4 } & & M & SD \\
\hline 9 & I have difficulty in using correct tenses in writing. & 4.40 & .90 \\
10 & I have difficulties in using correct structures in writing. & 4.03 & .52 \\
11 & I can't differentiate between formal structures and informal ones. & 4.42 & .90 \\
\hline
\end{tabular}

- Academic writing difficulties in unity and coherence

Table 7 shows that the mean score of difficulties in academic writing in terms of unity and coherence. Particularly, difficulties in focusing on the main ideas of the writing had a higher mean score (item 16: $\mathrm{M}=3.61, \mathrm{SD}=.72$ ) than linking ideas in writing (item 17: $\mathrm{M}=3.48, \mathrm{SD}=.72$ ). 
Table 5. English-majored students' academic writing difficulties in terms of supporting ideas

\begin{tabular}{clccc}
\hline \multirow{2}{*}{ No. } & \multicolumn{1}{c}{2 items } & \multicolumn{2}{c}{$\mathbf{N = 1 2 6}$} \\
\cline { 3 - 4 } & & I cannot find ideas relevant to topic. & 4.40 & SD \\
\hline 13 & I have difficulties in finding supporting ideas. & 3.45 & .88 \\
\hline
\end{tabular}

Table 6. English-majored students' academic writing difficulties in terms of punctuation/capitalization

\begin{tabular}{clcc}
\hline \multirow{2}{*}{ No. } & \multicolumn{1}{c}{ 2 items } & \multicolumn{2}{c}{$\mathbf{N = 1 2 6}$} \\
\cline { 3 - 4 } & & M & SD \\
\hline 14 & I have difficulties in using punctuations, e.g. comma, stop, etc. & 4.40 & .62 \\
15 & I have difficulties in using capitalization. & 4.40 & .82 \\
\hline
\end{tabular}

Table 7. English-majored students' academic writing difficulties in terms of unity and coherence

\begin{tabular}{clcc}
\hline \multirow{2}{*}{ No. } & \multicolumn{2}{c}{ 2 items } & \multicolumn{2}{c}{$\mathbf{N = 1 2 6}$} \\
\cline { 3 - 4 } & & M & SD \\
\hline 16 & I have difficulties in focusing on the main ideas of the writing. & 3.61 & .72 \\
17 & I don't know how to link ideas in writing. & 3.48 & .77 \\
\hline
\end{tabular}

\subsection{Discussion}

This study revealed some significant results. First, participants often faced a number of academic writing difficulties. One of the possible explanations for this may be due to the fact that their writing skills were low as seen from their writing scores in previous course were low. Nearly $50 \%$ of the research participants had less than 5.0 points out of 10 for their writing. Second, it was found out that participants encountered academic writing difficulties in deploying organization/ sequence and using grammar and punctuation/capitalization than the other aspects. The findings of the writing difficulties obtained in this research were similar to that of the study of Boonpattanaporn [8] and Luong and Nguyen [10]. They have found that participants often had difficulties in using grammar in writing. This is due to the fact that in Vietnamese the aspect of tenses does not significantly contribute to the meaning of the utterances since the time reference of the sentence could be expressed via means of words themselves, not grammatical aspects. According to Fadda [2], the principal difficulty faced by EFL students is grammar such as subject-verb agreement and connection of a group of words, usually containing a verb to form a logical and consistent paragraph because it is pretty challenging to distinguish between words and phrases in written and spoken forms. Moreover, this can lead to grammatical errors that may prevent students from interpreting and summarizing other people's compositions as stated by Amin and Alamin [6].

In terms of the organization of the paragraphs, the majority of the participants of the study expressed that it was hard to follow a certain structure of the text, especially the English style of writing. English styles of expressions are certainly different from Vietnamese ways of making voice heard. In the English language, the first sentence often contains the most crucial idea, and the following ones would be considered as secondary carrying the role of supporting the topic. Meanwhile, Vietnamese language does not require a norm like that. Wenyu and Yang [13] pointed out that students following an obvious description of the main facts about writing topics and a certain set of decisions about how to write those topics can easily organize their ideas and connect them to each other. Based on students' answers, the explanation for this problem may be that their understanding of coherence, the academic terms, the English structures and the organization of academic writing is barely adequate. Therefore, it is understandable that Vietnamese students would find it hard to master the structure or 
the organization of the essays or paragraphs. It would take some time for the learners and teachers to get used to a new style of writing in the situation of learners not writing often in their real life. Such a finding is partially corroborated with that of the study conducted by Chi and Nguyen [11] who found that the lack of understanding the writing style could contribute to the prevention of producing good writing.

Furthermore, participants stated that they found punctuation to be one of the most difficult aspects in writing. This was quite opposite to the expectation. However, this is explainable when we think of Vietnamese, a language that would accept a long sentence with commas being considered as the separation of the ideas while the English language requires a strict rule of punctuation. Some discussions of the relevant research on punctuation errors suggested that it is necessary for EFL students to know the meaning of the importance and purpose of special symbols that they add to writing to separate phrases and sentences to express what they are writing. In particular, Carey [14] pointed out that the meaning of punctuation is to take away ambiguity and create an understandable connection among words. Besides, according to Connelly [15], vagueness can stem from the use of irregular punctuation. In addition, Truss [16] declared that clear meaning can be conveyed through correct punctuation. This result was similar to Awad's [7] study. He found out the various common punctuation mistakes made by English-majored students. His findings showed that students were marked down for poor punctuation because of their unsuitable punctuation. For instance, they used the comma in place of the full-stop. Similarly, Adas and Bakir [5] and Gomez [9] addressed that students got hard to do their writing and to use punctuation. As stated by Gomez [9], an extensive number of commas were used in students' English statements.

\section{Conclusion}

This study has come to conclusion that English majored students encountered academic writing difficulties always in organization/sequence in writing, grammar and punctuation / capitalization but often in vocabulary, supporting ideas, and unity and coherence. This conclusion may recommend that students should practice in relation to these language areas on a more regular basis. One of the strategies they can adopt for overcoming such weaknesses is to seek peer support and mutual correction. In this way, learners can make use of peer corrective feedback in terms of lexical use, knowledge of grammar, and textual and mechanical elements in the process of practicing academic writing with peers. Also, they can consult their academic writing teachers for language support in cases in which their peers are unable to help them with the corrections. Most importantly, learners can make use of online resources for samples of academic writing texts as well as free writing correction services. Additionally, learners are advised to read extensively as the more they read, the more they can improve their writing skills. As for teachers, it is imperative that they should frequently utilize motivational approaches in order to foster their students' resilience in developing academic writing skills. To this end, teachers can provide students with more practice tasks that focus on areas of academic writing with which their students are still struggling.

This study still bears some limitations. First, the sample size was not big enough to make a generalization, so the findings may not be representing the whole picture of the topic of studies. Second, the questions in the questionnaire may not cover all the aspects of writing and the answer may possibly fall on other different categories. Only one research instrument was employed for data collection; therefore, the collected information may not be sufficient for all aspects of writing. 


\section{REFERENCES}

[1]. G. M. A. Grami, "The effects of integrating peer feedback into university-level ESL writing curriculum: A comparative study in a Saudi context," Unpublished doctoral dissertation, Newcastle University, 2010.

[2]. H. A. Fadda, "Difficulties in academic writing: From the perspective of King Saud University postgraduate students," English Language Teaching, vol. 5, no. 3, pp. 123130, 2012.

[3]. C. P. Casanave and P. Hubbard, "The Writing Assignments and Writing Problems of Doctoral Students: Faculty Perceptions, Pedagogical Issues, and Needed Research," English for Specific Purposes, vol. 11, no. 1, pp. 33-49, 1992.

[4]. G. Rabab'ah, "Communication problems facing Arab learners of English: A personal perspective," TEFL Web Journal, vol. 2, no.1, pp. 15-30, 2003.

[5]. D. Adas and A. Bakir, "Writing difficulties and new solutions: Blended learning as an approach to improve writing abilities," International Journal of Humanities and Social Science, vol. 3, no. 9, pp. 254-266, 2013.

[6]. S. Amin and A. Alamin, "Skills and strategies used in the comprehension and production of academic writing in Taif University," English Language and Literature Studies, vol. 2, no. 3, pp. 135-139, 2012.

[7]. A. Awad, "The most common punctuation errors made by the English and the TEFL majors at An-Najah National University," An-Najah University Journal for Research (Humanities), vol. 26, no. 1, pp. 211-233, 2012.

[8]. P. Boonpattanaporn, "Comparative study of English essay writing strategies and difficulties as perceived by English major students: A case study of students in the School of Humanities, University of Thai
Chamber of Commerce," The University of Thai Chamber of Commerce Academic Journal, vol. 28, no. 2, pp. 76-90, 2008.

[9]. L. Gomez, "Writing trouble spots for ESL students of Arabic: The apple where teachers meet and learn," Teaching Community, 2010. [Online]. Available: http://teaching. monster. com/benefits/articles/10068-5-writingtrouble-spotsfor-esl-students-of-arabic [Accessed June, 2, 2020].

[10]. Q. T. Luong and T. M. H. Nguyen, "Students writing process, perceptions, problems, and strategies in writing academic essays in a second language: a case study," VNU Journal of Science, Foreign Languages, vol. 24, pp. $184-197,2008$.

[11]. D. N. Chi and X. N. C. M. Nguyen, "Paraphrasing in Academic Writing: a Case Study of Vietnamese Learners of English," Language Education in Asia, vol. 8, no. 1, pp. 9-24, 2017.

[12]. J. Tanaka, "Academic difficulties among East Asian international graduate students: influences of perceived English language proficiency and native educational/sociocultural background," Indiana University TESOL Quarterly, vol. 29, pp. 235-260, 2002.

[13]. L. Wenyu and L. Yang, "Research on EFL writing strategies using SRP: An empirical study in DUT," The Asian EFL Journal, vol. 10, pp. 51-83, 2008.

[14]. G. Carey, Mind the stop: A brief introduction to pronunciation. New York: Penguin Books, 1978.

[15]. M. Connelly, Get writing: Sentences and paragraphs. Florence, KY: Cengage Learning, 2009.

[16]. L. Truss, Eats shoots and leaves: The zero tolerance approach to punctuation. New York: Gotham Books, 2003. 